\title{
Multimission empirical ocean tide modeling for shallow waters and polar seas
}

\author{
Yongcun Cheng ${ }^{1,2}$ and Ole Baltazar Andersen ${ }^{1}$ \\ Received 30 March 2011; revised 29 July 2011; accepted 4 August 2011; published 1 November 2011.
}

[1] A new global ocean tide model named DTU10 (developed at Technical University of Denmark) representing all major diurnal and semidiurnal tidal constituents is proposed based on an empirical correction to the global tide model FES2004 (Finite Element Solutions), with residual tides determined using the response method. The improvements are achieved by introducing 4 years of TOPEX-Jason 1 interleaved mission into existing 18 years (1993-2010) of primary joint TOPEX, Jason 1, and Jason 2 mission time series. Hereby the spatial distribution of observations are doubled and satellite altimetry should be able to recover twice the spatial variations of the tidal signal which is particularly important in shallow waters where the spatial scale of the tidal signal is scaled down. Outside the $\pm 66^{\circ}$ parallel combined Envisat, GEOSAT Follow-On, and ERS-2, data sets have been included to solve for the tides up to the $\pm 82^{\circ}$ parallel. A new approach to removing the annual sea level variations prior to estimating the residual tides significantly improved tidal determination of diurnal constituents from the Sun-synchronous satellites (e.g., ERS-2 and Envisat) in the polar seas. Extensive evaluations with six tide gauge sets show that the new tide model fits the tide gauge measurements favorably to other state of the art global ocean tide models in both the deep and shallow waters, especially in the Arctic Ocean and the Southern Ocean. One example is a comparison with 207 tide gauge data in the East Asian marginal seas where the root-mean-square agreement improved by $35.12 \%, 22.61 \%, 27.07 \%$, and $22.65 \%\left(\mathrm{M}_{2}, \mathrm{~S}_{2}, \mathrm{~K}_{1}\right.$, and $\left.\mathrm{O}_{1}\right)$ for the DTU10 tide model compared with the FES2004 tide model. A similar comparison in the Arctic Ocean with 151 gauge data improved by $9.93 \%$, $0.34 \%, 7.46 \%$, and $9.52 \%$ for the $\mathrm{M}_{2}, \mathrm{~S}_{2}, \mathrm{~K}_{1}$, and $\mathrm{O}_{1}$ constituents, respectively.

Citation: Cheng, Y., and O. B. Andersen (2011), Multimission empirical ocean tide modeling for shallow waters and polar seas, J. Geophys. Res., 116, C11001, doi:10.1029/2011JC007172.

\section{Introduction}

[2] Accurate ocean tide prediction is crucial for many purposes such as investigating the variability of the sea surface currents and eddy activities [e.g., Xiu et al., 2010]. Nowadays, 18 years of satellite altimeter observations have been available since 1993 in the same ground track through the TOPEX, Jason 1, and Jason 2 missions, which makes it possible to separate most of the tidal constituents from each other. Many efforts and methods have been applied to study altimetric tide modeling [e.g., Cartwright and Ray, 1990; Ray, 1993; Egbert et al., 1994; Andersen, 1994, 1995; Eanes and Bettadpur, 1996; Andersen and Knudsen, 1997] and shallow water tides [e.g., Andersen, 1999; Andersen et al., 2006; Ray, 2007; Egbert et al., 2010].

${ }^{1}$ DTU Space, Danish National Space Center, Technical University of Denmark, Copenhagen, Denmark.

${ }^{2}$ Also at State Key Laboratory of Satellite Ocean Environment Dynamics, Second Institute of Oceanography, State Oceanic Administration, Hangzhou, China.

Copyright 2011 by the American Geophysical Union. 0148-0227/11/2011JC007172
[3] The state of the art global ocean tide models include GOT4.7 (successive updates from GOT99.2 [Ray, 1999]), FES2004 (Finite Element Solutions [Lyard et al., 2006]), EOT10a [Savcenko and Bosch, 2008], TPXO7.2 [Egbert and Erofeeva, 2002] and HAMTIDE (E. Taguchi et al., manuscript in preparation, 2010). All two empirical models (EOT10a and GOT4.7) are have been derived as corrections to prior hydrodynamic models (FES2004 was used for EOT10a and FES94.1 was used for GOT4.7). The FES2004 model was initially computed on a dense finite element grid, but the released solutions have been resampled to an equal latitude-longitude grid with a spatial resolution of $0.125^{\circ}$. This resampling means that in a few coastal regions, the FES2004 model had to be extended toward the coast to enable spatiotemporal interpolation to altimetric observations. This was done using repetition of the closest cell value.

[4] Compared with state of the art tide model accuracy of 2-3 cm in the open ocean, tidal modeling in shallow waters and polar seas are far less accurate [Andersen, 1994; Shum et al., 1997; Fok et al. 2010]. Not only have significant short wavelength errors in coastal regions been recently demonstrated by comparing ocean tide models with high-resolution 
hydrodynamic modeling (e.g., HAMTIDE) [Bosch et al., 2009], but also long wavelength errors have been demonstrated using temporal gravity field observations by the Gravity Recovery and Climate Experiment (GRACE) [Ray et al., 2009]. In the polar seas outside the coverage of TOPEX altimetry $\left( \pm 66^{\circ}\right)$, satellite data such as Envisat, ICESat, and CryoSat-2 data are impacted by tide prediction errors owning to a general lack of high-quality observational constraints [Peacock and Laxon, 2004; Kwok et al., 2006; Ray et al., 2003, 2010].

[5] In this work, a new global ocean tide model DTU10 is developed as an empirical correction to the FES2004 ocean tide model using the response method for residual tide analysis. The FES2004 solutions assimilated 337 TOPEX and 1254 ERS altimetric crossover points and 671 tide gauge data into a time stepping finite element hydrodynamic model. However, the DTU10 is the first empirical tide model to use both 18 years of data collected from the joint TOPEX, Jason 1, and Jason 2 nominal ground tracks during the primary mission (hereinafter simplified as "PRIMARY"). TOPEX was moved to interleaved ground tracks during the last 2 years of its lifetime. Similarly, Jason 1 was moved to the same interleaved ground tracks 2 years ago providing a total of 4 years of joint TOPEX and Jason 1 data (hereinafter "INTERLEAVED") for tidal prediction, hereby doubling the spatial distribution of observations. The improvements of using interleaved ground track data in tide estimation will be demonstrated in section 5. Subsequently, extensive evaluations with other state of the art ocean tide models, using six tide gauge data sets show that the new tide model fits tide gauge measurements favorably in both deep ocean, shallow waters and polar seas.

\section{Alias Periods}

[6] The tidal signal has much higher frequency than the sampling of the satellite $(0.5 \mathrm{~d}$ versus $9.9 \mathrm{~d}$ sampling for TOPEX, Jason 1, and Jason 2). Therefore, the tidal signal is aliased into periods longer than 20 d [Andersen, 1995; Andersen and Scharroo, 2010]. In Table 1, the tidal alias periods of the most prominent tidal constituents are shown for TOPEX (Jason 1 and Jason 2) and Envisat (ERS-2), respectively. The alias periods are shown in the diagonal. The off-diagonal elements are the minimum time span of data required to separate the tidal constituents from each other, which are also called the alias synodic periods by Fang et al. [2004]. The minus sign in front of the alias period means that the advance of the tidal phase over a repeat cycle is negative.

[7] Table 1 illustrates the problem of estimating ocean tides from various altimetric satellites. Even though the orbit configuration for the TOPEX and Jason satellites was designed to optimally recover ocean tides [Parke et al., 1987], some small problems still exist. One example is the two largest semidiurnal constituent $\mathrm{M}_{2}$ and $\mathrm{S}_{2}$, which are aliased into a signal with a period of $62 \mathrm{~d}$ and $59 \mathrm{~d}$ by the $9.9156 \mathrm{~d}$ sampling of TOPEX, Jason 1, and Jason 2, respectively. Consequently at least $1084 \mathrm{~d}$ (3 years) are needed to separate $M_{2}$ from $S_{2}$ which is critical to the INTERLEAVED mission. The alias period for the $\mathrm{MS}_{4}$ compound tide (created by the interaction between $\mathrm{M}_{2}$ and $\mathrm{S}_{2}$ ) will is also $1084 \mathrm{~d}$ [Andersen et al., 2006] indicating the difficulty of estimating several compound tide from
TOPEX, Jason 1, and Jason 2, observations. Moreover, 10 years $(3355 \mathrm{~d})$ of time series are required to separate $\mathrm{K}_{2}$ from $\mathrm{P}_{1}$ and $\mathrm{K}_{1}$ from the semiannual sea level variation $\mathrm{S}_{\mathrm{sa}}$.

[8] The alias period is much more problematic for the Sunsynchronous ERS-2 and Envisat satellites. The $\mathrm{S}_{2}$ is always seen having the same phase during every repeat period so that $S_{2}$ constituent appears as a constant height. In addition, the $\mathrm{M}_{2}$ and $\mathrm{N}_{2}$ tidal constituents require 9 years (3169 d) of satellite observations to be separated. The diurnal constituents $\mathrm{K}_{1}$ and $\mathrm{P}_{1}$ have alias periods of exactly 1 year (365 d), which makes them inseparable from the annual signal $\left(\mathrm{S}_{\mathrm{a}}\right)$ and each other. Furthermore most shallow water constituents will be nearly impossible to be determined from ERS-2 and Envisat altimetry as the primary constituents like $\mathrm{S}_{2}$ are difficult to be determined [Andersen, 1999].

\section{Data}

\subsection{Satellite Altimetry}

[9] The altimetric observations are taken from the RADS (Radar Altimeter Database System) database applying state of the art altimeter corrections including the FES2004 for the tidal correction (ocean and loading). In RADS the raw altimeter sea level are interpolated to along-track normal points and provided as a time series of collocated observations. The joint T/P-Jason missions provide a maximum of 665 and 182 repeat cycles of data from the PRIMARY and INTERLEAVED mission, respectively. As an example, the ground track distribution of PRIMARY (thin lines) and INTERLEAVED (bold lines) in the East Asian marginal seas (EAMS) are shown in Figure 1 and it is seen that the use of INTERLEAVED data basically doubles the spatial distribution of data which is of fundamental importance in shallow waters.

[10] The combined Envisat, GEOSAT Follow-On (GFO), and ERS-2 data have only been used for tidal analysis outside the $\pm 66^{\circ}$ parallel where TOPEX, Jason 1, and Jason 2 data are not available. Because of the fact that the accuracy of altimetric observations degrades at high latitude because of the presence of sea ice, a cell approach is taken to increase the number of observations. By choosing a cell size which is large enough, each cell will contain several independent descending and ascending tracks as well as observations from both ERS-2/Envisat and GFO (inside the $\pm 72^{\circ}$ parallel). The downside of this approach is that the resolution of the recovered tidal signal is limited by the size of the cell. However, the additional data from several adjacent are important for tide prediction in the polar seas [Andersen, 1994].

[11] In this study, a maximum of 225 cycles (Envisat (90 cycles), GFO (140 cycles) and ERS-2 (120 cycles)) during the year from 1995 to 2010 have been used and a cell size of $1^{\circ}$ in latitude by $5^{\circ}$ in longitude was selected to ensure more than 7 descending and 7 ascending tracks in every cell ensuring observations from at least 14 independent tracks within each $35 \mathrm{~d}$ cycle (naturally limited by the presence of sea ice in some regions). The $1^{\circ}$ by $5^{\circ}$ box sizes vary in size from $111 \times 226 \mathrm{~km}$ to $111 \times 77 \mathrm{~km}$ between latitude $\pm 66^{\circ}$ and $\pm 82^{\circ}$.

\subsection{Tide Gauge Data}

[12] Six different tide gauge data sets have been compiled to validate the new tide model in this study. Figure 2 shows 
Table 1. Alias Periods (Diagonal) and Alias Synodic Periods (Off Diagonal) for TOPEX (Jason) and Envisat (ERS-2/Envisat), Respectively ${ }^{\mathrm{a}}$

\begin{tabular}{lcccccccccl}
\hline & $\mathrm{M}_{2}$ & $\mathrm{~S}_{2}$ & $\mathrm{~N}_{2}$ & $\mathrm{~K}_{2}$ & $\mathrm{~K}_{1}$ & $\mathrm{O}_{1}$ & $\mathrm{P}_{1}$ & $\mathrm{Q}_{1}$ & $\mathrm{~S}_{\mathrm{sa}}$ & $\mathrm{S}_{\mathrm{a}}$ \\
\hline \multicolumn{8}{c}{ TOPEX/POSEIDON (Jason 1 and Jason 2) } \\
$\mathrm{M}_{2}$ & 62 & $\mathbf{1 0 8 4}$ & 245 & 220 & 97 & 173 & 206 & 594 & 94 & 75 \\
$\mathrm{~S}_{2}$ & & -59 & 316 & 183 & 89 & 206 & 173 & 384 & 87 & 70 \\
$\mathrm{~N}_{2}$ & & & -50 & 116 & 69 & 594 & 112 & 173 & 68 & 57 \\
$\mathrm{~K}_{2}$ & & & & -87 & 173 & 97 & $\mathbf{3 3 5 5}$ & 349 & 165 & 114 \\
$\mathrm{~K}_{1}$ & & & & & -173 & 62 & 183 & 116 & $\mathbf{3 3 5 5}$ & 329 \\
$\mathrm{O}_{1}$ & & & & & & 46 & 94 & 134 & 61 & 52 \\
$\mathrm{P}_{1}$ & & & & & & -89 & 316 & 173 & 118 \\
$\mathrm{Q}_{1}$ & & & & & & & -69 & 112 & 86 \\
$\mathrm{~S}_{\mathrm{sa}}$ & & & & & & & & 183 & 365 \\
$\mathrm{~S}_{\mathrm{a}}$ & & & & & & & & & 365
\end{tabular}

\begin{tabular}{lllllllllll}
\multicolumn{10}{c}{ Envisat (ERS-2) } \\
$\mathrm{M}_{2}$ & -95 & 95 & 3169 & 196 & 128 & 365 & 128 & 328 & 196 & 128 \\
$\mathrm{~S}_{2}$ & $\infty$ & 97 & 183 & 365 & 75 & 365 & 133 & 183 & 365 \\
$\mathrm{~N}_{2}$ & & 97 & 209 & 133 & 328 & 133 & 365 & 209 & 133 \\
$\mathrm{~K}_{2}$ & & & 183 & 365 & 127 & 365 & 487 & $\infty$ & 365 \\
$\mathrm{~K}_{1}$ & & & & $\mathbf{3 6 5}$ & 95 & $\infty$ & 209 & 365 & $\infty$ \\
$\mathrm{O}_{1}$ & & & & & -75 & 95 & 173 & 128 & 95 \\
$\mathrm{P}_{1}$ & & & & & & $-\mathbf{3 6 5}$ & 209 & 365 & $\infty$ \\
$\mathrm{Q}_{1}$ & & & & & & & 133 & 487 & 209 \\
$\mathrm{~S}_{\mathrm{sa}}$ & & & & & & & & 183 & 365 \\
$\mathrm{~S}_{\mathrm{a}}$ & & & & & & & & & 365 \\
\hline
\end{tabular}

aThe alias periods are given in days and the "problematic" alias periods for altimetric tide retrieval are shown in bold.

the locations of the six tide gauge sets. The first data set called ST-102 [Shum et al., 1997] is the mainly pelagic ocean data set used to evaluate the altimetric tide models, most of which are located in the open ocean. The second is a combination of pelagic and coastal harmonic constituents derived from the World Ocean Circulation Experiment

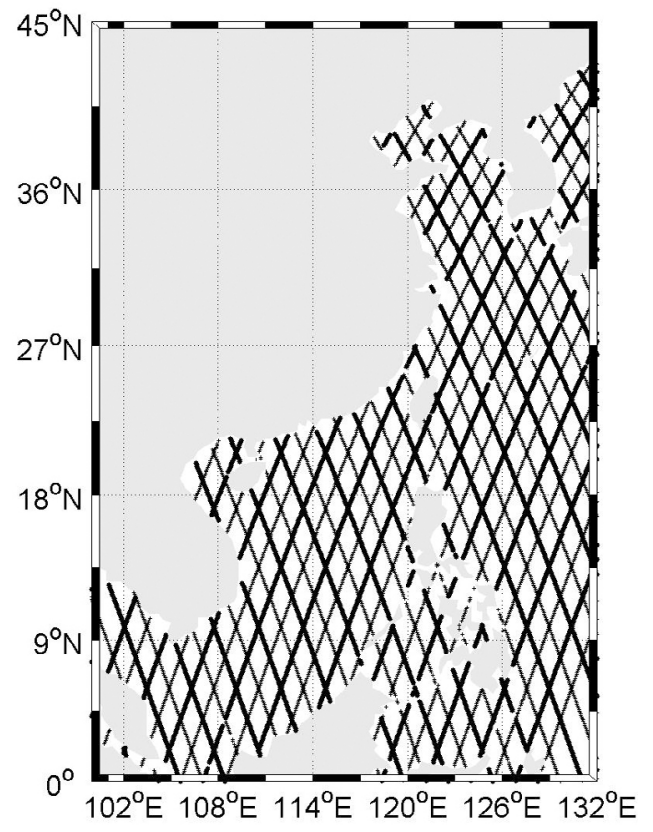

Figure 1. Joint TOPEX, Jason 1, and Jason 2 ground track of PRIMARY mission (thin lines) and INTERLEAVED mission (bold lines) in the East Asian marginal seas. See section 1 for explanation of "PRIMARY" and "INTERLEAVED."
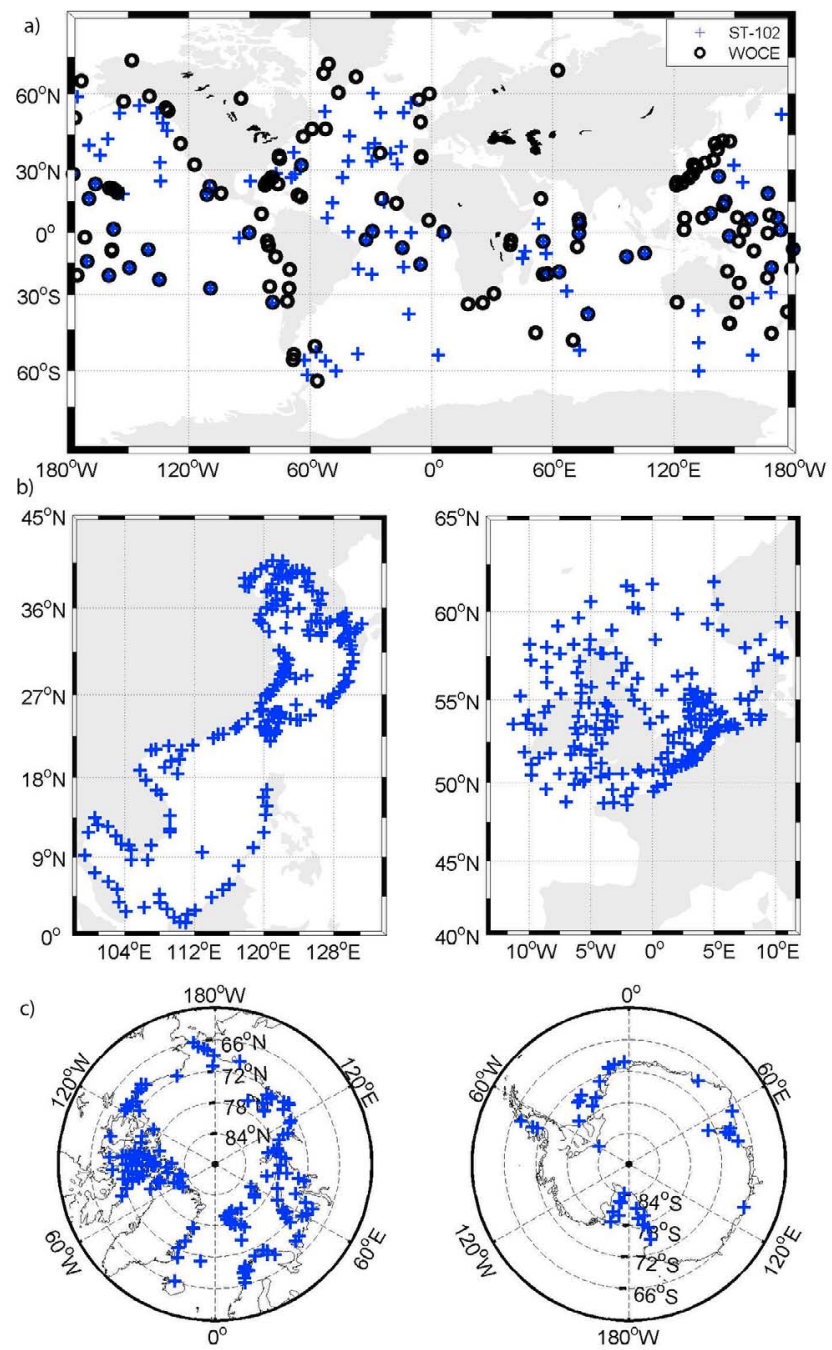

Figure 2. Locations of tide gauge data sets from (a) ST-102 (pluses) and World Ocean Circulation Experiment (WOCE) (circles), (b) East Asian marginal seas (EAMS) and the northwest European Shelf region (NES), and (c) the Arctic Ocean and the Southern Ocean.

(WOCE) sea level observations (available from http://www. bodc.ac.uk/). The northwest European shelf region (NES) and EAMS are characterized by some of the largest semidiurnal tides in the world and are obvious places to evaluate the ocean tide models. The third data set is a 195 NES mainly coastal tide gauge set [Andersen et al., 2006]. The fourth data set is 207 gauges in the EAMS region compiled from published literatures [Fang et al., 1999, 2004; Lin et al., 2001; Cheng et al., 2007].

[13] The fifth tide gauge data set is a collection of 151 gauges in the Arctic Ocean [Padman and Erofeeva, 2004] and the final tide gauge data set is 37 gauges in the Southern Ocean [King and Padman, 2005; King et al., 2005] (available from http://www.ims.uaf.edu/tide/ and http://www.esr.org/ antarctic tg index.html). This Southern Ocean data set is a collection of data from bottom pressure recorder as well as GPS, gravimeter and wire length loggers on ice shelves. The phase lags are referred to local time zone in the EAMS and the 

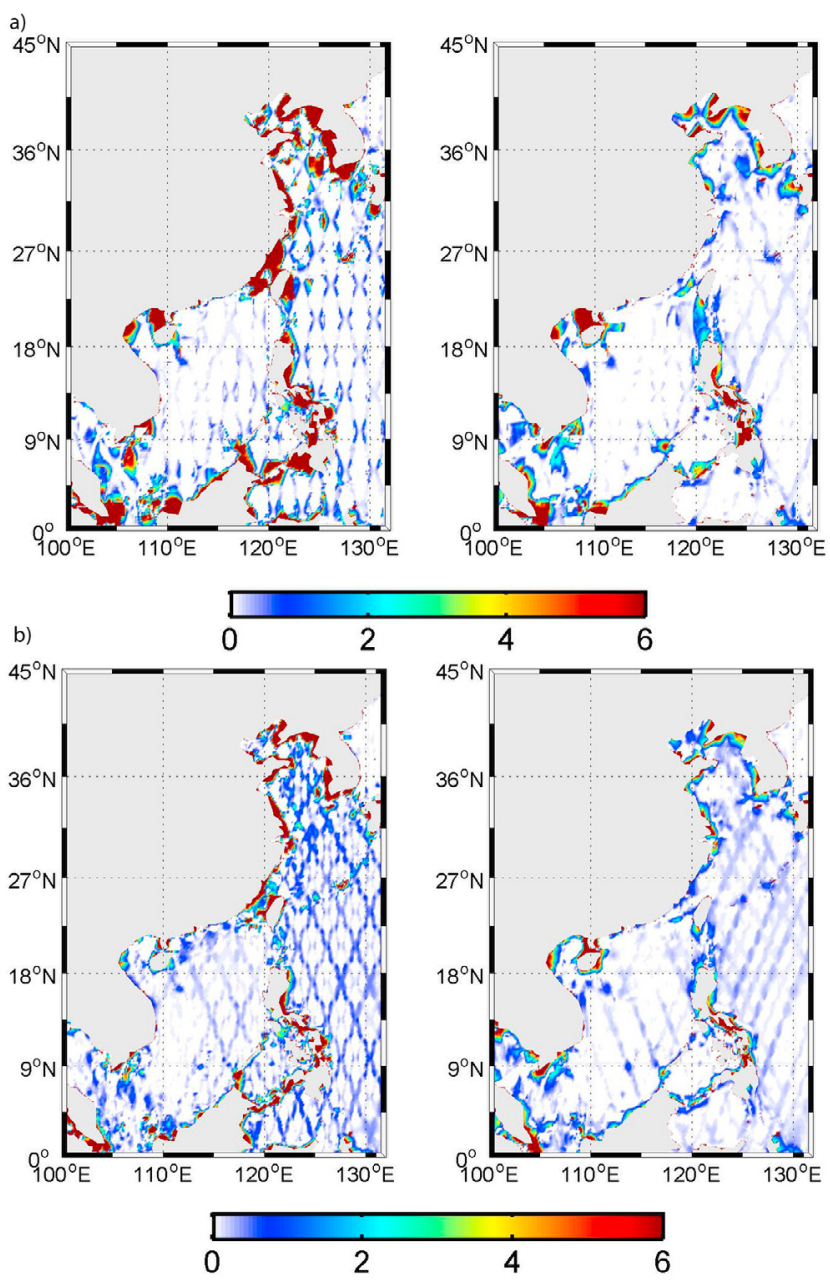

Figure 3. Difference between original FES2004 amplitudes and predicted FES2004 amplitudes using simulated FES2004 data along (a) PRIMARY (17 years) ground tracks and (b) PRIMARY (17 years) and INTERLEAVED (4 years) ground tracks. Difference for $\mathrm{M}_{2}$ is shown to the left and $\mathrm{K}_{1}$ to the right in centimeters.

Arctic Ocean data sets are transferred to Greenwich phase lags using the equations of Fang et al. [1999].

\section{Global Tidal Prediction}

[14] The along-track sea level residuals (or compiled cell observations in polar seas) are analyzed using the response method [Munk and Cartwright, 1966] extended with the orthotide formalism by Cartwright and Ray [1990] and Andersen [1994, 1995, 1999] in their analysis of altimetry data. The advantage of using the response method is as follows: by assuming a smooth admittance function described by a relatively low number of parameters within each tidal band (orthotide parameters). Hence a solution for any constituent can be inferred. Ma et al. [1994] and Ray [1998] have shown that the response method works well with TOPEX altimeter and performs equally accurate as the harmonic analysis method even though fewer parameters are estimated.

[15] For Envisat (ERS-2), the obvious advantage in the polar seas is the fact that the $\mathrm{S}_{2}, \mathrm{~K}_{1}$ and $\mathrm{P}_{1}$ tidal constituents

can be inferred even though their alias periods are problematic. However, there are some limitations to this as the admittance function can only be accurately defined if the tidal signal is clearly present in the data. The dominating $\mathrm{M}_{2}$ signal generally ensures the working in the semidiurnal band, but for the diurnal band the problem is that the annual sea level variation is of the same order as the residual tide signal. The investigation in section 5.2 demonstrates that considerable improvement in tidal prediction can be obtained if the annual signal is removed prior to performing tidal estimation and hereby enhancing the "tidal" signal to noise in the data.

[16] The output of the tidal analysis are cosine and sine coefficients (or in phase and in quadrature) for each tidal constituent which are computed as linear combinations of the orthotide coefficients [Cartwright and Ray, 1990; Andersen, 1995] and these are subsequently interpolated onto the FES2004 grid using the dynamic interpolation method as described by Andersen [1999] which takes the tidal wavelength for diurnal and semidiurnal waves into account as well as the water depth. This is done by using collocation with a second-order Markov covariance function as

$$
C(r, D)=C_{0}(1+r / \alpha(D)) e^{(-r / \alpha(D))}
$$

where $\alpha(D)$ is the correlation length related to the water depth $D, r$ is the spatial distance and $C_{0}$ is the error variance. Several investigations showed that the best results were obtained if the modification was done between the depth of 2000 and $20 \mathrm{~m}$ using correlation length of the residual tidal signal of $1000 \mathrm{~km}$ at $200 \mathrm{~m}$ depth and $200 \mathrm{~km}$ at $20 \mathrm{~m}$ depth. Outside these depth bounds the water depth was set equal to the water depth at the bounds. Similarly the correlation length was doubled for diurnal tides to account for the longer tidal wavelength compared with semidiurnal tides. The water depths were taken from DNSC08 bathymetry model [Andersen and Knudsen, 2009].

[17] As satellite altimetry observes the combined ocean and loading tide, the residual tidal constituents were corrected for residual loading signal in order to derive ocean tide signal. The residual loading is conveniently be approximated using a 4\% assumption [e.g., Agnew, 1997]. Finally, the FES2004 ocean tide grids for each constituents were added back to obtain the full ocean tide model.

\section{Ocean Tide Model Results}

\subsection{Impacts of TOPEX and Jason 1 Interleaved Mission Data on Tide Estimates}

[18] With the availability of 4 years of TOPEX and Jason 1 INTERLEAVED data the major semidiurnal constituents $\mathrm{M}_{2}$ and $\mathrm{S}_{2}$ are now separable from these data, which means that altimetric tidal prediction from the dedicated "tide" satellites (TOPEX, Jason 1, and Jason 2) can be made twice at many locations as before. In principle this means that satellite altimetry should be able to recover twice the spatial variations of the tidal signal. However, in the deep ocean the tidal wavelength [Andersen, 1999] is so long that inclusion of these additional data will only have marginal importance. The importance is found in shallow waters where the changes in bathymetry scale the tidal signal down and create very complex tidal signals with much shorter wavelength. 
Table 2. The RMS (cm) Difference Between FES2004 Solutions and the Predicted Amplitudes of the $\mathrm{M}_{2}$ and $\mathrm{K}_{1}$ Tidal Constituents in the East Asian Marginal Seas

\begin{tabular}{|c|c|c|}
\hline & $\mathrm{M}_{2}$ & $\mathrm{~K}_{1}$ \\
\hline $\begin{array}{l}\text { Only use PRIMARY data from TOPEX, Jason 1, } \\
\text { and Jason } 2\end{array}$ & 21.30 & 2.09 \\
\hline Use both PRIMARY and INTERLEAVED ${ }^{\mathrm{a}}$ data & 12.27 & 1.40 \\
\hline
\end{tabular}

asee section 1 for explanation of "PRIMARY" and "INTERLEAVED."

[19] In order to study the impacts of supplementing PRIMARY data with 4 years of INTERLEAVED data, a simulation was performed using the FES2004 ocean tide model. In this experiment 18 years of PRIMARY and 4 years of INTERLEAVED sea level observations at all along-track normal points were simulated using the FES2004 ocean tide model. Subsequently, the tidal constituents were estimated from these observations using the response method and interpolated onto the FES2004 grid using the method described in section 4. The ability to predict the FES2004 tide signal from satellite altimetry was inspected by comparing the derived model with the original FES2004 model. Figure 3 displays the differences between the original FES2004 and estimated FES2004 amplitude for the $\mathrm{M}_{2}$ and $\mathrm{K}_{1}$ tidal constituents in the EAMS region. In Figure $3 \mathrm{a}$ only altimetric observations along the PRIMARY ground tracks were used to derive the tidal model whereas in Figure $3 b$ the INTERLEAVED tidal estimates were added.

[20] The comparison of Figure 3b with Figure 3a demonstrates a dramatic improvement in reproducing the FES2004 ocean tide model when the INTERLEAVED data is introduced especially in the coastal waters of the Eastern China Sea, the west of Korean Peninsula, the Qiongzhou Strait, and the coastal regions of the Malaysia and the Philippines. The largest improvement is seen in the Taiwan Strait where an interleaved ground track is crossing. In Figure $3 b$, the INTERLEAVED ground track stands out with higher error

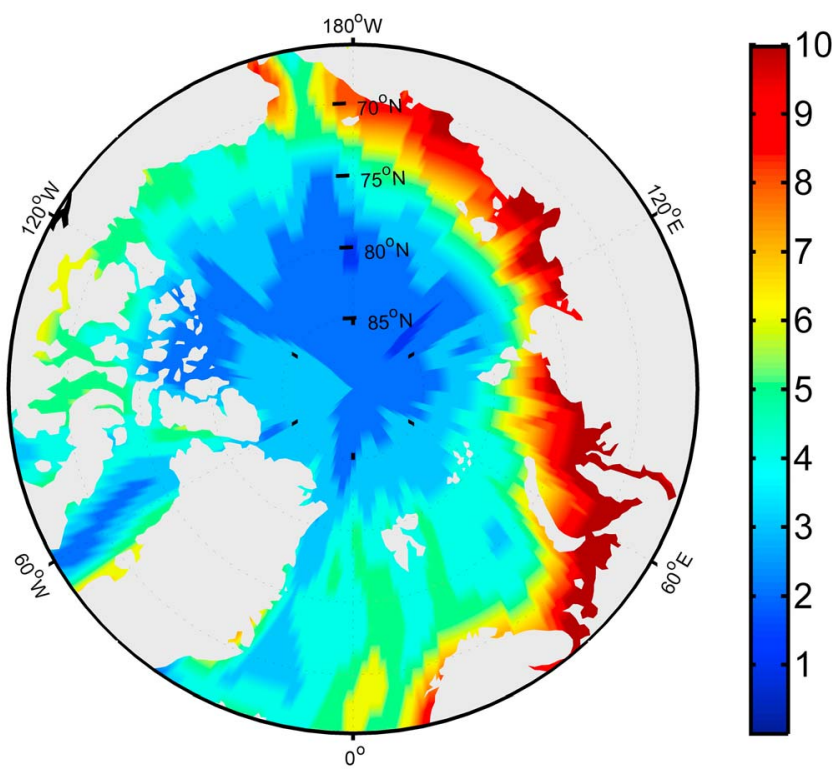

Figure 4. Amplitude $(\mathrm{cm})$ of the annual sea level signal in the Arctic Ocean from the DTU10ANN model. than the PRIMARY ground tracks because of much fewer observations along the INTERLEAVED tracks (4 years versus 18 time span of PRIMARY data).

[21] The root-mean-square (RMS) of the tidal differences in all grid cells of the FES2004 model within the EAMS region $\left(22.5 \mathrm{~N}^{\circ}-45 \mathrm{~N}^{\circ}, 119^{\circ} \mathrm{E}-129^{\circ} \mathrm{E}\right)$ is listed in Table 2 demonstrating the importance of including the INTERLEAVED data. The surprisingly large RMS difference for the dominating $\mathrm{M}_{2}$ constituent is a consequence of the fact that the computation is done for all points in the FES2004 model grid and not only in the ground track points where the tidal estimate is generally very accurate. In between the altimeter tracks the tidal prediction relies on the skill of the interpolation method used.

\subsection{Impacts of Modeling the Annual Signal}

[22] When using altimetric data from the Sun-synchronous satellites ERS-2 and Envisat in polar seas, the alias period of the largest diurnal constituent $\mathrm{K}_{1}$ has an alias period of
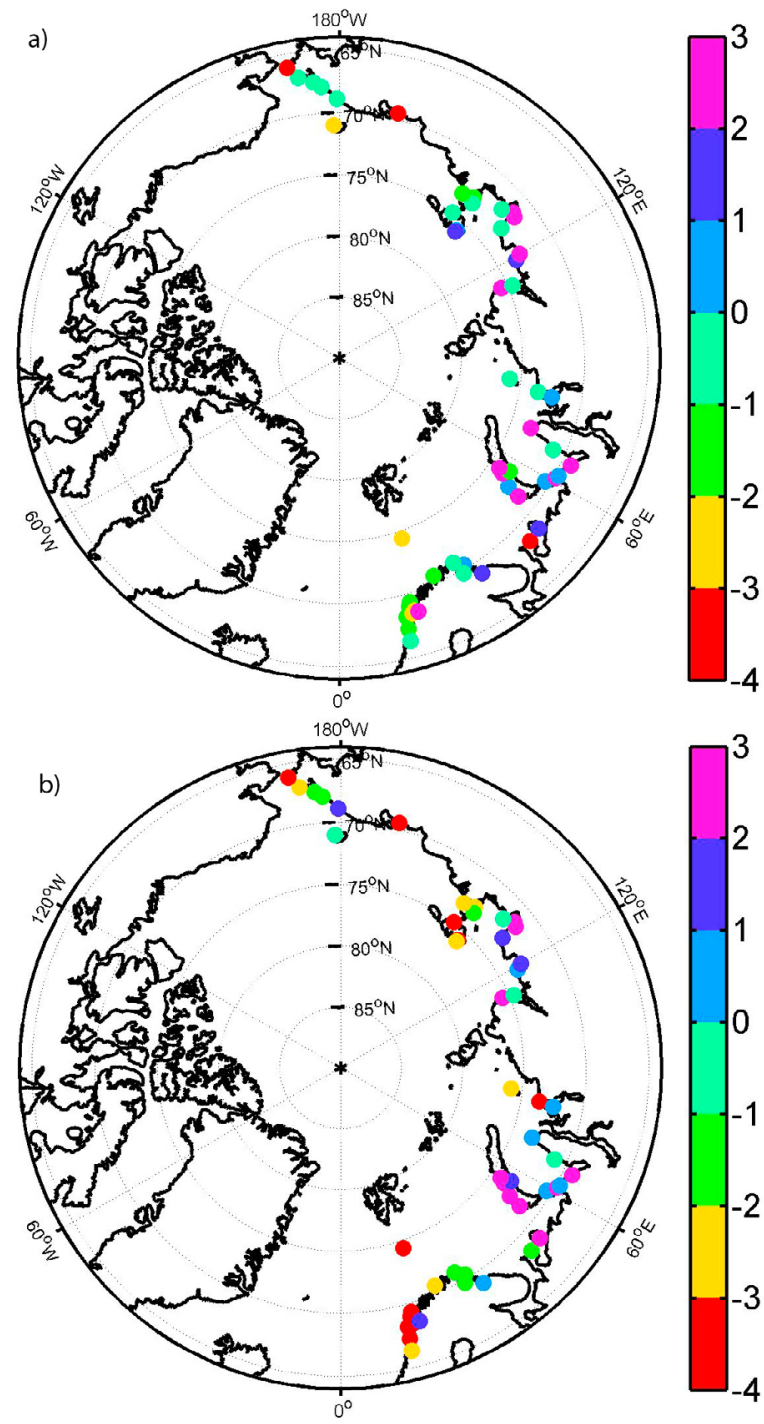

Figure 5. $\mathrm{K}_{1}$ amplitude difference $(\mathrm{cm})$ between tide gauge measurements and the model prediction (a) with and (b) without prior removal of the annual sea level signal. 

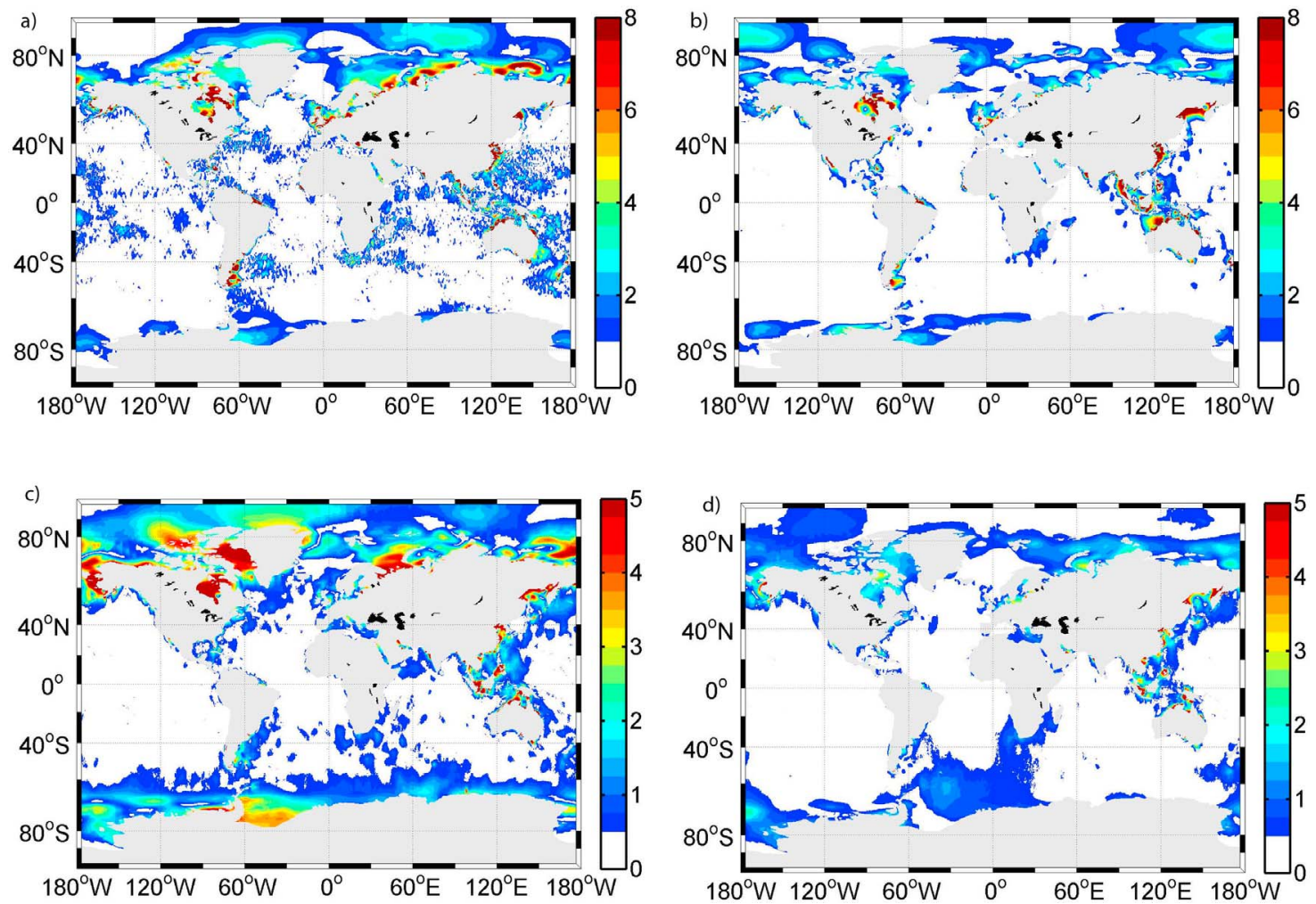

Figure 6. Amplitude difference $(\mathrm{cm})$ between the FES2004 and the DTU10 ocean tide model for the (a) $\mathrm{M}_{2}$, (b) $\mathrm{S}_{2}$, (c) $\mathrm{K}_{1}$, and (d) $\mathrm{O}_{1}$ constituent. The colors are set to white for residuals less than 1 and $0.5 \mathrm{~cm}$ for $\mathrm{M}_{2}\left(\mathrm{~S}_{2}\right)$ and $\mathrm{K}_{1}\left(\mathrm{O}_{1}\right)$, respectively.

exactly 1 year making it inseparable from the annual sea level signal. In the Arctic region, the problem is particularly large as the amplitude of the annual signal is comparable to the residual ocean tide signal (between 0 and $15 \mathrm{~cm}$ ).

[23] An attempt to overcome this problem was taken by Andersen [1994] who extended the response formalism to simultaneously solve for the annual signal, but the success was limited. A better result can be obtained by applying a correction for the annual variation prior to determining the residual ocean tide signal as the following investigation show. In this case a hybrid altimetric-hydrological model called DTU10ANN (available from ftp://ftp.space.dtu.dk/ pub/DTU10) was used to remove the annual sea level variation. This model has been derived by long wavelength adjustment of the annual sea level signal from GECCO [Köhl and Stammer, 2008a, 2008b] using satellite altimetry within the coverage of the TOPEX satellites and tide gauges elsewhere and the amplitude of the annual sea level signal in the Arctic Ocean is shown in Figure 4.

[24] A test was carried out in the Arctic Ocean in which the tidal prediction was performed with and without applying the correction for the annual sea level signal prior to ocean tide estimation. Subsequently the predicted tidal estimates for the $\mathrm{K}_{1}$ constituent were compared with 51 tide gauge data in the Arctic Ocean along the coast of Northern Europe/Russia. Figure 5 displays the difference between tide gauge measurements and the model predictions of the $\mathrm{K}_{1}$ constituent. The annual sea level signal was removed prior to residual tidal estimation in Figure 5a but not in Figure 5b. The amplitude difference decreases in 39 out of 51 tide gauges when applying the correction for the annual variation in sea level, and Figure 5 shows that particularly the Norwegian gauges benefits from the approach. Overall this improved the amplitude agreement for the $\mathrm{K}_{1}$ constituent between tide gauge and tide model by $28.72 \%$.

\subsection{Global Ocean Tide Residuals}

[25] The residual ocean tide signal relative to the FES2004 for the $\mathrm{M}_{2}, \mathrm{~S}_{2}, \mathrm{~K}_{1}$ and $\mathrm{O}_{1}$ constituents are shown in Figure 6 estimated from a combination of PRIMARY and INTERLEAVED data. The amplitudes of all residual constituents are generally very small in the deep ocean and considerable signals are only found in some coastal and polar seas. In some coastal regions, e.g., the Sea of Okhotsk, EAMS, NES, the North of Australia and on the Patagonian shelf, the residual $\mathrm{M}_{2}$ tidal exceeds $5 \mathrm{~cm}$ as seen in Figure $6 \mathrm{a}$. The amplitude pattern of the residual $S_{2}$ in Figure $6 \mathrm{~b}$ is roughly similar to the $\mathrm{M}_{2}$ pattern except generally smaller. Compared with the difference between the EOT08a and FES2004 [Savcenko and Bosch, 2008], the large $S_{2}$ residual amplitude along the equator $(1-2 \mathrm{~cm})$ is not seen in this analysis. Figures $6 \mathrm{c}$ and $6 \mathrm{~d}$ shows residual amplitudes for the major diurnal constituents $\mathrm{K}_{1}$ and $\mathrm{O}_{1}$ constituents, respectively. Residuals larger than a few $\mathrm{cm}$ are only found in coastal regions and at high latitudes.

[26] Significant residual amplitudes are also found in the Arctic regions particularly for the $\mathrm{M}_{2}$ and $\mathrm{K}_{1}$ constituents where areas with residual tidal amplitudes up to or even above 8 and $5 \mathrm{~cm}$, respectively, are found. For $\mathrm{M}_{2}$, the high residuals appear mainly in coastal regions and in the Barents 


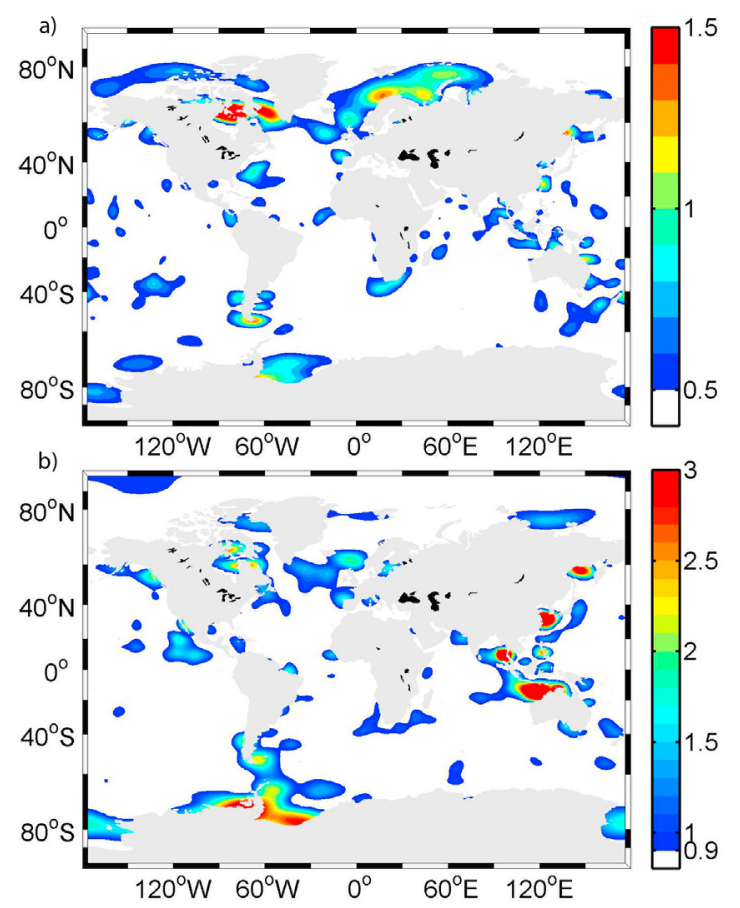

Figure 7. Gravity Recovery and Climate Experiment (GRACE) residual tide estimates $(\mathrm{cm})$ relative to the FES2004 from 8 years of Centre National d'Etudes Spatiales/Le Groupe de Recherche de Géodésie Spatiale data: (a) $\mathrm{M}_{2}$ tide residual; (b) $\mathrm{S}_{2}$ tide residual. The colors are set to white for residuals less than 0.5 and $0.9 \mathrm{~cm}$ for $\mathrm{M}_{2}$ and $\mathrm{S}_{2}$, respectively.

Sea, the Kara Sea, the Laptev Sea as well as close to the New Siberian Islands, the Wrangel Island and in the Hudson Bay. For $\mathrm{K}_{1}$, the high residuals are found in the Barents Sea, the Chukchl Sea, the Beaufort Sea as well as in the Baffin Bay and around the Wrangel Island and the Queen Elizabeth Islands.

[27] Generally the residual tides are much smaller in the Southern Ocean than in the Arctic Ocean with only significant amplitudes found in the Weddel Sea, the Larsen Ice Shelf, the Bellingshausen Sea and the Ross Sea. For $\mathrm{K}_{1}$ residuals up to $5 \mathrm{~cm}$ are only found in the Bellingshausen Sea. Some smaller discontinuity in $\mathrm{K}_{1}$ residual tide are seen at both at the $66^{\circ} \mathrm{N}$ and $66^{\circ} \mathrm{S}$ parallel. This seems to be caused by the transition from TOPEX, Jason 1, and Jason 2 to the combined Envisat, GFO, and ERS-2 observations and points toward problems in the definition of the diurnal admittance function when using Envisat, GFO, and ERS-2 observations (even when applying a correction for the annual variation in sea level).

\subsection{Validation With Water Mass Variations From GRACE}

[28] Deficiencies in ocean tide modeling will also show up in temporal gravity field models from GRACE as the mass associated with the mismodeled tidal bulge can be sensed by the GRACE twin satellites and consequently the GRACE gravity field observations can be used to validate the new ocean tide particularly in regions of poor tide gauge coverage like the polar seas. The Centre National d'Etudes
Spatiales/Le Groupe de Recherche de Géodésie Spatiale (CNES/GRGS) water mass variations grids are provided as $10 \mathrm{~d}$ averaged grids (Release-02) [Bruinsma et al., 2010] for the period from August 2002 to August 2010 giving a total of 267 grids ( 15 periods missing). All standard corrections have been applied to the GRACE data. The details of the data are available from http://grgs.obs-mip.fr/index.php/fre/ Donnees-scientifiques/Champ-de-gravite/grace/release 02 .

[29] The alias periods for the $\mathrm{M}_{2}$ and $\mathrm{S}_{2}$ constituents are shown by Ray and Luthcke [2006] to be $13.52 \mathrm{~d}$ and $161 \mathrm{~d}$, respectively. GRACE fields are delivered as $10 \mathrm{~d}$ average over the available dates in that interval, hence it is possible to analyze the data below the Nyquist frequency $(20 \mathrm{~d}$ for a $10 \mathrm{~d}$ sampling) and consequently a least squares fitting of cosine and sine signals with the $\mathrm{M}_{2}$ and $\mathrm{S}_{2}$ frequencies were performed and the results are shown in Figure 7. Because of the spatial resolution of the GRACE data only wavelength down to spatial scales of $400 \mathrm{~km}$ will be mapped. Different tidal frequencies will be averaged differently in the $10 \mathrm{~d}$ averaging process as was shown by Knudsen and Andersen [2002]. The $\mathrm{S}_{2}$ constituent will not be dampened, but $\mathrm{M}_{2}$ will be attenuated nearly 3 times for a $10 \mathrm{~d}$ averaging. Consequently $\mathrm{M}_{2}$ will stand out with reduced amplitude compared with $\mathrm{S}_{2}$. In terms of comparing with altimetry tide prediction, GRACE is most conveniently used to investigate regions of coherent tidal residuals. The combination of the attenuation and short alias period means that the error on the $\mathrm{M}_{2}$ tidal estimation will be high and explain why some open ocean regions exhibit a false $\mathrm{M}_{2}$ signal (e.g., Gulf Stream region).

[30] Figures 7a and $7 \mathrm{~b}$ show the $\mathrm{M}_{2}$ and $\mathrm{S}_{2}$ residual ocean tide signals derived from GRACE relatively to the FES2004, respectively. The residual speaks at similar locations to that derived from multimission altimetry (Figures 6a and 6b), respectively. For $\mathrm{M}_{2}$ tide residual (comparing Figures $7 \mathrm{a}$ and 6a) coherent residual signals are found in the Sea of Okhotsk, EAMS, NES, the Northern Australia and over the Patagonian shelf. In the Arctic Ocean, the coherent residual signal are found in the Hudson Bay and the Hudson Strait, an area of inordinately large tides, the Laptev Sea and the East Siberian Sea. In the Southern Ocean, the coherent residuals are found in the Ross Sea and the Weddel Sea. The Comparing Figure $7 \mathrm{~b}$ with Figure $7 \mathrm{a}$, the larger $\mathrm{S}_{2}$ tide residuals are found in the Sea of Okhotsk, EAMS, the Northwest of Australia, the Weddel Sea, over the Patagonian shelf and around the Larsen Ice Shelf.

\section{Comparison With Tide Gauge Data}

\subsection{In Shallow Water and Deep Water}

[31] Validations against tide gauge data have previously proven invaluable for testing and even improving open ocean tide models [e.g., Ray et al., 2010]. In this section the four data sets outside the polar seas (see Figure 2) are used to investigate the performance of the new global tide model. Several state of the art ocean tide models are included for cross validation include FES2004, EOT10a, TPX07.2, GOT4.7 and HAMTIDE11a. This selection is not comprehensive, but includes those models that have been most commonly applied by various research groups. Bilinear interpolation method is used to compare with the tide gauge data for all models. In order to perform comparison with all models with 
Table 3. RMSe $(\mathrm{cm})$ and Root-Sum-Square $(\mathrm{cm})$ Between the Interpolated Tidal Signal From Various Models and Tide Gauges for the Four Major Tidal Constituents for the Four In Situ Data Sets ${ }^{\mathrm{a}}$

\begin{tabular}{|c|c|c|c|c|c|c|}
\hline \multirow[b]{2}{*}{ Wave } & \multicolumn{6}{|c|}{ Resolution and RMSe $(\mathrm{cm})$} \\
\hline & DTU10 $\left(0.125^{\circ}\right)$ & FES2004 $\left(0.125^{\circ}\right)$ & EOT10a $\left(0.125^{\circ}\right)$ & TPXO7.2 $\left(0.25^{\circ}\right)$ & GOT4.7 $\left(0.5^{\circ}\right)$ & HAMTIDE11a $\left(0.125^{\circ}\right)$ \\
\hline \multicolumn{7}{|c|}{$S T-102(102)^{\mathrm{b}}$} \\
\hline $\mathrm{M}_{2}$ & 1.23 & 1.33 & 1.30 & 1.29 & 1.29 & 1.31 \\
\hline $\mathrm{S}_{2}$ & 0.86 & 0.89 & 0.87 & 0.89 & 0.92 & 0.90 \\
\hline $\mathrm{K}_{1}$ & 1.08 & 1.09 & 1.05 & 1.20 & 1.12 & 1.18 \\
\hline $\mathrm{O}_{1}$ & 0.92 & 0.93 & 0.91 & 0.94 & 0.97 & 1.02 \\
\hline RSS & 2.07 & 2.15 & 2.09 & 2.19 & 2.17 & 2.30 \\
\hline \multicolumn{7}{|c|}{ World Ocean Circulation Experiment (199) } \\
\hline $\mathrm{M}_{2}$ & 2.89 & 2.90 & 2.80 & 4.20 & 5.89 & 6.09 \\
\hline $\mathrm{S}_{2}$ & 1.72 & 1.71 & 1.61 & 2.23 & 2.41 & 3.09 \\
\hline $\mathrm{K}_{1}$ & 1.88 & 2.05 & 1.90 & 2.23 & 2.05 & 1.53 \\
\hline $\mathrm{O}_{1}$ & 1.76 & 1.73 & 1.69 & 2.01 & 1.81 & 1.75 \\
\hline RSS & 4.24 & 4.30 & 4.11 & 5.62 & 6.93 & 7.16 \\
\hline \multicolumn{7}{|c|}{ Northwest European Shelf Region (195) } \\
\hline $\mathrm{M}_{2}$ & 12.58 & 14.63 & 14.18 & 15.13 & 16.40 & 23.03 \\
\hline $\mathrm{S}_{2}$ & 8.24 & 9.15 & 8.65 & 6.80 & 7.98 & 10.09 \\
\hline $\mathrm{K}_{1}$ & 1.46 & 1.65 & 1.59 & 1.56 & 1.51 & 1.78 \\
\hline $\mathrm{O}_{1}$ & 1.10 & 1.21 & 1.36 & 1.21 & 1.30 & 1.66 \\
\hline RSS & 15.15 & 17.38 & 16.74 & 16.70 & 18.35 & 25.27 \\
\hline \multicolumn{7}{|c|}{ East Asian Marginal Seas (207) } \\
\hline $\mathrm{M}_{2}$ & 14.41 & 22.21 & 17.80 & 25.35 & 13.65 & 16.05 \\
\hline $\mathrm{S}_{2}$ & 8.08 & 10.44 & 8.68 & 11.29 & 8.17 & 10.00 \\
\hline $\mathrm{K}_{1}$ & 3.53 & 4.84 & 4.05 & 7.36 & 4.16 & 5.37 \\
\hline $\mathrm{O}_{1}$ & 3.21 & 4.15 & 3.57 & 6.30 & 3.47 & 4.44 \\
\hline RSS & 17.20 & 25.36 & 20.53 & 29.39 & 16.80 & 20.16 \\
\hline
\end{tabular}

${ }^{a}$ Numbers marked in bold indicate the smallest RMSe and root-sum-square (RSS) among the various models.

${ }^{\mathrm{b}}$ Data set and number of data.

coastal tide gauges some models (particularly FES2004) were extended toward the coast using simple repetition of the value in the closest ocean cell.

[32] Table 3 displays the comparison for the four major tidal constituents with the four data sets. The upper comparisons with the ST-102 open ocean data set indicate that all state of the art models compares more or less equally well in the deep ocean. The most recent empirical ocean tide models (DTU10 and the EOT10a) shows marginally better fit to the ST-102 measurements as well as the WOCE199 data set which must be explained by the fact that these two models use both longer altimetric time series and data from more satellites.

[33] In shallow waters and coastal regions, the DTU10 ocean tide model generally performs best in the comparison with the NES and EAMS data sets. Compared with the 195 gauge data in the NES region DTU10 reduces the root sum of squares (RSS) of all constituents with nearly $13 \%$ compared with that from FES2004. The validation against 207 coastal tide gauge data in the EAMS region shows improvements in the RMSes of $35.12 \%, 22.61 \%, 27.07 \%$ and $22.65 \%\left(\mathrm{M}_{2}, \mathrm{~S}_{2}, \mathrm{~K}_{1}\right.$ and $\left.\mathrm{O}_{1}\right)$ for the new model compared with the FES2004. GOT4.7 outperforms other models for the $\mathrm{M}_{2}$ constituent in the EAMS regions, which might be due to the fact that GOT4.7 is augmented with a local hydrodynamic model for the Eastern China Sea.

[34] It also can be seen from Table 2 that the accuracy of $\mathrm{S}_{2}$ tide in shallow water and coastal regions from DTU10 tide model is still not satisfying when comparing with tide gauge derived harmonic constituents. The RMSe is 8.24 and $8.08 \mathrm{~cm}$ from NES and EAMS data sets are high compared with the amplitude of the constituent. Particularly in the EAMS region where the amplitude of the $S_{2}$ constituent is only slightly larger than the $\mathrm{K}_{1}$ and $\mathrm{O}_{1}$ constituents, but the discrepancy with tide gauge is still double of that with $\mathrm{K}_{1}$ and $\mathrm{O}_{1}$. This points toward problems of using the admittance method on $\mathrm{S}_{2}$ derivation, linked with the existence of a significant radiational $S_{2}$ tide in the ocean, exhibiting amplitudes of several centimeters at midlatitudes and low latitudes [Ray, 1998]. Formal harmonic analysis will associate astronomical and radiational $\mathrm{S}_{2}$ tide simultaneously, thus tide gauges constituents will contain both contributions. However, the admittance method will filter out most of the radiational $\mathrm{S}_{2}$ tide leaving only the astronomic part in the solution, which might be responsible for the high difference seen in the region.

[35] To detailed inspect the performance of the global ocean tide model in coastal regions Figure 8 shows the differences of cosine and sine coefficients for the major semidiurnal and diurnal constituents interpolated from the model and observed by tide gauge in the NES region which is the shallowmost region investigated here. For both $\mathrm{M}_{2}$ and $\mathrm{K}_{1}$, the DTU10 solutions agree well with the ground truth and generally the fit is within the $5 \mathrm{~cm}$ bound, but some consistent regions of large errors are seen. One such region is the Dutch coast. As all tide models tested exhibit the same systematic discrepancy with the Dutch gauges and as the problem is evident for several constituents, this could point toward the gauges being systematically wrong, but it could also points toward the general problem in modeling the tides in the North Sea, namely a combination of very complex nonlinear tides, and the fact that bathymetry is not 

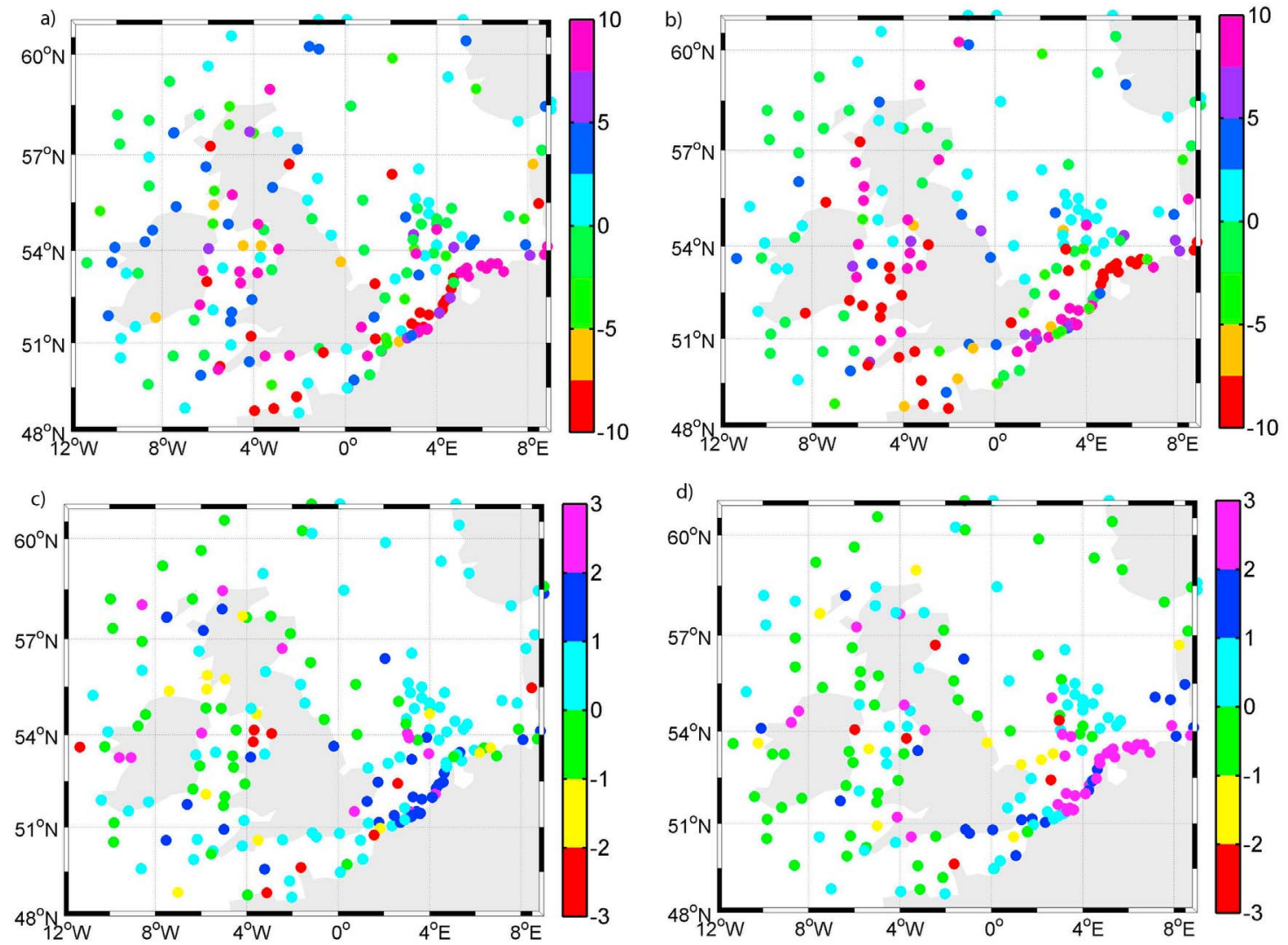

Figure 8. Amplitude difference $(\mathrm{cm})$ between tide gauge constituent and interpolated constituent from the DTU10 ocean tide model: (a) $\mathrm{M}_{2}$ cosine, (b) $\mathrm{M}_{2}$ sine, (c) $\mathrm{K}_{1}$ cosine, and (d) $\mathrm{K}_{1}$ sine.

determined adequate enough for tidal modeling in the region. Some other regions of systematic errors are found in the Irish Sea where the difference between gauge value and model solutions is positive indicating that the tide models generally underestimate the tides in this region.

\subsection{Validation in the Polar Seas}

[36] Ocean tides in the polar seas play an important role in global climate change and particularly for the correction of space observations [Holloway and Proshutinsky, 2007]. Beside the traditional numerical methods [e.g., Padman and Erofeeva, 2004], intersatellite ranging data from GRACE has also been used [e.g., Han et al., 2007, 2010; Ray et al., 2009]. Tidal constituents have been retrieved at 151 tide gauges located outside the $66^{\circ} \mathrm{N}$ parallel to validate recent ocean tide models in the Arctic Ocean. In the Southern Ocean data derived from 37 tide gauges, bottom pressure recorders as well as global positioning system, gravimeter and wire length loggers on ice shelves.

[37] In polar regions, the extensions of ice edge influent the tidal prediction as it affect the roughness of the ocean surface. In the Arctic Ocean, the big difference between tide gauge and ocean tide model estimated harmonic constituents are always found over the Queen Elizabeth Islands (not shown here). Two reasons maybe explain the misfit the effects from ice and the complex distribution of islands combined with the fact that the regions were nearly always covered by ice.
[38] In the Southern Ocean, the tides under the large Weddell Sea ice shelves are among the least well observed on Earth. King et al. [2011] compared the tidal constituents from harmonic analysis with model outputs from FES2004, TPXO7.2 and GOT4.7. It was mentioned tides under FilchnerRonne ice shelves are particularly poorly modeled. They hypothesized that the errors were due mainly to inaccurate water column thicknesses under Filchner-Ronne ice shelves because of a lack of water column thickness data.

[39] Table 4 lists the comparison of the amplitudes of the four major tidal constituents $\left(\mathrm{M}_{2}, \mathrm{~S}_{2}, \mathrm{~K}_{1}\right.$ and $\left.\mathrm{O}_{1}\right)$. In addition, the high-resolution barotropic tide model AOTIM (the Arctic Ocean Tidal Inverse Model) [Padman and Erofeeva, 2004] have been included for the Arctic Ocean and a medium-resolution regional inverse model of the entire Southern ocean CADA00.10 [Padman et al., 2002] are included for cross validation. Generally the agreement with tide gauges are substantially worse than what is that seen inside the $66^{\circ}$ parallel. This will partly be caused by the tide gauges themselves being more inaccurate, but the main cause is the lack of accurate TOPEX, Jason 1, and Jason 2 satellite altimetry. Consequently, most tidal models have to rely on hydrodynamic modeling outside $66^{\circ}$ parallel.

[40] It can be seen from Table 4 that the performance of EOT10a is similar to FES2004 in the polar seas. This is naturally a cause of the heritage of the EOT10 being computed as corrections to FES2004 (inside the $66^{\circ}$ parallel). Compared with other models, the amplitudes of the four 
Table 4. RMSe (cm) and RSS $(\mathrm{cm})$ Between the Tidal Amplitudes From Model Outputs and Tide Gauge Measurements for the Four Major Tidal Constituents in the Arctic and Southern Ocean, Respectively ${ }^{\mathrm{a}}$

\begin{tabular}{|c|c|c|c|c|c|c|c|c|}
\hline \multirow{2}{*}{$\begin{array}{c}\text { Data Set } \\
\text { and Number } \\
\text { of Data }\end{array}$} & \multirow[b]{2}{*}{ Wave } & \multicolumn{7}{|c|}{ Resolution and RMSe $(\mathrm{cm})$} \\
\hline & & $\begin{array}{l}\text { DTU10 } \\
0.125^{\circ}\end{array}$ & $\begin{array}{c}\text { FES2004 } \\
0.125^{\circ}\end{array}$ & $\begin{array}{c}\text { EOT10a } \\
0.125^{\circ}\end{array}$ & $\begin{array}{c}\text { TPXO } 7.2 \\
0.25^{\circ}\end{array}$ & $\begin{array}{c}\text { GOT } 4.7 \\
0.5^{\circ}\end{array}$ & $\begin{array}{l}\text { HAMTI E11a } \\
0.125^{\circ}\end{array}$ & $\begin{array}{c}\text { AOTIM } \\
5 \mathrm{~km}\end{array}$ \\
\hline \multirow{5}{*}{ Arctic (151) } & $\mathrm{M}_{2}$ & 5.35 & 5.94 & 5.93 & 14.31 & 6.83 & 6.38 & 15.94 \\
\hline & $\mathrm{S}_{2}$ & 2.91 & 2.92 & 2.92 & 4.36 & 3.38 & 3.19 & 6.54 \\
\hline & $\mathrm{K}_{1}$ & 2.48 & 2.68 & 2.67 & 3.56 & 3.70 & 2.70 & 3.81 \\
\hline & $\mathrm{O}_{1}$ & 1.71 & 1.89 & 1.91 & 9.08 & 1.89 & 1.72 & 1.92 \\
\hline & RSS & 6.79 & 7.38 & 7.38 & 17.86 & 8.68 & 7.82 & 17.75 \\
\hline \multirow{3}{*}{$\begin{array}{l}\text { Data Set } \\
\text { and Number } \\
\text { of Data }\end{array}$} & \multicolumn{8}{|c|}{ Resolution and RMSe $(\mathrm{cm})$} \\
\hline & & DTU10 & FES2004 & EOT10a & ТРХО 7.2 & GOT 4.7 & HAMTIDE11a & CADA \\
\hline & Wave & $0.125^{\circ}$ & $0.125^{\circ}$ & $0.125^{\circ}$ & $0.25^{\circ}$ & $0.5^{\circ}$ & $0.125^{\circ}$ & 00.10 \\
\hline \multirow{5}{*}{$\begin{array}{r}\text { The Southern } \\
\text { Ocean (37) }\end{array}$} & $\mathrm{M}_{2}$ & 2.83 & 3.17 & 3.15 & 4.65 & 4.86 & 14.12 & 4.05 \\
\hline & $\mathrm{S}_{2}$ & 3.84 & 3.82 & 3.82 & 4.56 & 4.40 & 9.80 & 4.55 \\
\hline & $\mathrm{K}_{1}$ & 4.03 & 4.31 & 4.28 & 5.18 & 6.72 & 6.83 & 4.78 \\
\hline & $\mathrm{O}_{1}$ & 4.67 & 4.85 & 4.82 & 4.73 & 5.46 & 6.96 & 3.93 \\
\hline & RSS & 7.80 & 8.17 & 8.13 & 9.57 & 10.86 & 19.72 & 8.68 \\
\hline
\end{tabular}

${ }^{a}$ Numbers marked in bold indicate the smallest RMSe and RSS among the various.

major tidal constituents derived from the DTU10 gives favorable agreement to most other global models. Compared with the FES2004 that DTU10 adjusts, the RMSes from the DTU10 are improved by $9.93 \%, 0.34 \%, 7.46 \%$ and $9.52 \%$ for $\mathrm{M}_{2}, \mathrm{~S}_{2}, \mathrm{~K}_{1}$ and $\mathrm{O}_{1}$ tidal constituents, respectively.

[41] The comparison with the 37 Southern Ocean tide gauges is also listed in Table 4 which indicates roughly similar RSS as for the Arctic Ocean. However, for the Southern Ocean the largest errors are seen for the diurnal constituents, which are very large in this region. The larger errors for HAMTIDE11a might be caused by the limitation of the tide model at $78.375^{\circ} \mathrm{S}$, which means that the tides under the Ross Ice Shelf cannot be properly predicted. Again, the DTU10 ocean tide model gives more favorable agreement than other global tide models for particularly the diurnal constituents. The GOT4.7 model seems to have some problems in predicting particularly the diurnal constituents which might be inherited from the underlying FES94.1 ocean tide model and the high latitudes.

[42] If the annual signal in the sea level residuals were not removed prior to the tidal prediction, the RMSe between the predicted amplitude of $\mathrm{K}_{1}$ and in situ measurements would be 2.92 and $4.28 \mathrm{~cm}$ in the Arctic Ocean and the Southern Ocean, corresponding to increased error of $17.74 \%$ and $6.02 \%$, respectively. Actually, this would make the $\mathrm{K}_{1}$ constituent from DTU10 equally accurate to the FES2004 (and hereby EOT10a) as the RMS with tide gauges are improved by $10.73 \%,-0.52 \%, 6.50 \%$ and $3.71 \%$ for $\mathrm{M}_{2}$, $\mathrm{S}_{2}, \mathrm{~K}_{1}$ and $\mathrm{O}_{1}$ tidal constituents, respectively, when comparing FES2004 and DTU10 to tide gauges.

\section{Summary}

[43] The development of the new global ocean tide model DTU10 from multimission altimetry data identified significant residual ocean tide signal in particularly shallow waters and at high latitudes. The response method is used for along-track residual analysis of 18 years of data from the primary tracks and 4 years of interleaved tracks. The importance of including the INTERLEAVED data was demonstrated through a simulation of the FES2004 ocean tide model and indicated the importance of these new data to improve ocean tide signal in shallow waters where the spatial scale of the tides decreases.

[44] Another significant improvement was the introduction of a model for the annual signal in the polar seas. The removal of annual signal in the sea level residuals in the combined Envisat, GFO, and ERS-2 satellite altimeter data prior to tidal prediction significantly lowers the contribution of nontidal variability at the aliased tidal frequencies and improves the determination of the admittance functions and hereby the ocean tide constituents.

[45] The new model is assessed with six tide gauge data sets. The results show its improvement in the global tide prediction accuracy. The comparison of harmonic constants for the four major tidal constituents derived from tide gauge records shows that all recent tide models perform equally well in the deep ocean (comparison with the 102 tide gauge set). However, the new DTU10 model solutions gives favorable agreement to that derived from tide gauge records in deep and shallow waters as well as in the polar seas.

[46] Acknowledgments. The research is a contribution to the projects MyOcean and Monitoring and Assessing Regional Climate change in High latitudes and the Arctic (MONARCH), which both are granted by the European Commission within the Global Monitoring for Environment and Security Program (GMES, 7th Framework Program), the Open Fund of State Key Laboratory of Satellite Ocean Environment Dynamics (under grant SOED1104). We thank the Radar Altimeter Database System (RADS) for providing altimetry data and World Ocean Circulation Experiment (WOCE) sea level Data Assembly Centre for providing tide gauge harmonic constants.

\section{References}

Agnew, D. C. (1997), NLOADF: A program for computing ocean-tide loading, J. Geophys. Res., 102(B3), 5109-5110, doi:10.1029/96JB03458.

Andersen, O. B. (1994), Ocean tides in the northern North Atlantic Ocean and adjacent seas from ERS 1 altimeter, J. Geophys. Res., 99(C11), 22,557-22,573, doi:10.1029/94JC01433.

Andersen, O. B. (1995), Global ocean tides from ERS 1 and TOPEX/ POSEIDON altimeter, J. Geophys. Res., 100(C12), 25,249-25,259, doi:10.1029/95JC01389. 
Andersen, O. B. (1999), Shallow water tides on the northwest European shelf from TOPEX/POSEIDON altimeter, J. Geophys. Res., 104(C4), 7729-7741, doi:10.1029/1998JC900112.

Andersen, O. B., and P. Knudsen (1997), Multi-satellite ocean tide modelingThe $\mathrm{K}_{1}$ constituent, Prog. Oceanogr., 40, 197-216, doi:10.1016/S00796611(98)00002-0.

Andersen, O. B., and P. Knudsen (2009), DNSC08 mean sea surface and mean dynamic topography models, J. Geophys. Res., 114, C11001, doi:10.1029/2008JC005179.

Andersen, O. B., and R. Scharroo (2010), Range and geophysical corrections in coastal regions: And implications for mean sea surface determination, in Coastal Altimetry, edited by S. Vignudelli, et al., pp. 103-145, Springer, New York., doi:10.1007/978-3-642-12796-0 5.

Andersen, O. B., G. D. Egbert, S. Y. Erofeeva, and R. D. Ray (2006) Mapping nonlinear shallow-water tides: A look at the past and future, Ocean Dyn., 56, 416-429, doi:10.1007/s10236-006-0060-7.

Bosch, W., R. Savcenko, F. Flechtner, C. Dahle, T. Mayer-Gürr, D. Stammer, E. Taguchi, and K. H. Ilk (2009), Residual ocean tide signals from satellite altimeter, GRACE gravity fields, and hydrodynamic modeling, Geophys. J. Int., 178, 1185-1192, doi:10.1111/j.1365-246X.2009.04281.x.

Bruinsma, S., J. M. Lemoine, R. Biancale, and N. Valès (2010), CNES/ GRGS 10-day gravity field models (release 2 ) and their evaluation, Adv. Space Res., 45(4), 587-601, doi:10.1016/j.asr.2009.10.012.

Cartwright, D. W., and R. D. Ray (1990), Oceanic tides from Geosat altimeter, J. Geophys. Res., 95(C3), 3069-3090, doi:10.1029/JC095iC03p03069.

Cheng, Y. C., X. Lv, Y. Liu, and Q. Xu (2007), Application of adjoint assimilation technique in simulating tides and tidal currents of the Bohai Sea, the Yellow Sea and the East China Sea, High Technol. Lett., 13(1), 58-64.

Eanes, R., and S. Bettadpur (1996), The CSR 3.0 global ocean tide model: Diurnal and semidiurnal ocean tides from TOPEX/POSEIDON altimetry, Tech. Rep. CRS TM 96 05, Cent. for Space Res., Univ. of Tex. at Austin, Austin.

Egbert, G. D., and S. Y. Erofeeva (2002), Efficient inverse modeling of barotropic ocean tides, J. Atmos. Oceanic Technol., 19, 183-204, doi:10.1175/1520-0426(2002)019<0183:EIMOBO $>2$

Egbert, G. D., A. F. Bennett, and M. G. G. Foreman (1994), TOPEX POSEIDON tides estimated using a global inverse model, J. Geophys. Res., 99(C12), 24,821-24,852, doi:10.1029/94JC01894.

Egbert, G. D., S. Y. Erofeeva, and R. D. Ray (2010), Assimilation of altimeter data for nonlinear shallow-water tides: Quarter-diurnal tides of the Northwest European Shelf, Cont. Shelf Res., 30, 668-679, doi:10.1016/ j.csr.2009.10.011.

Fang, G. H., Y. K. Kwok, K. J. Yu, and Y. H. Zhu (1999), Numerical simulation of principal tidal constituents in the South China Sea, Gulf of Tonkin, and Gulf of Thailand, Cont. Shelf Res., 19, 845-869, doi:10.1016/S02784343(99)00002-3

Fang, G. H., Y. G. Wang, Z. X. Wei, B. H. Choi, X. Y. Wang, and J. Wang (2004), Empirical cotidal charts of the Bohai, Yellow, and East China Seas from 10 years of TOPEX/POSEIDON altimetry, J. Geophys. Res., 109, C11006, doi:10.1029/2004JC002484.

Fok, H. S., et al. (2010), Evaluation of ocean tide models used for Jason-2 altimeter corrections, Mar. Geod., 33, suppl. 1, 285-303, doi:10.1080/ 01490419.2010.491027.

Han, S.-C., R. D. Ray, and S. B. Luthcke (2007), Ocean tidal solutions in Antarctica from GRACE inter-satellite tracking data, Geophys. Res. Lett. 34, L21607, doi:10.1029/2007GL031540.

Han, S.-C., R. D. Ray, and S. B. Luthcke (2010), One centimeter-leve observations of diurnal ocean tides from global monthly mean time-variable gravity fields, J. Geod., 84, 715-729, doi:10.1007/s00190-010-0405-3.

Holloway, G., and A. Proshutinsky (2007), Role of tides in Arctic ocean/ice climate, J. Geophys. Res., 112, C04S06, doi:10.1029/2006JC003643.

King, M. A., and L. Padman (2005), Accuracy assessment of ocean tide models around Antarctica, Geophys. Res. Lett., 32, L23608, doi:10.1029/ 2005GL023901.

King, M. A., N. T. Penna, P. J. Clarke, and E. C. King (2005), Validation of ocean tide models around Antarctica using onshore GPS and gravity data, J. Geophys. Res., 110, B08401, doi:10.1029/2004JB003390.

King, M. A., L. Padman, K. Nicholls, P. J. Clarke, G. H. Gudmundsson, B. Kulessa, and A. Shepherd (2011), Ocean tides in the Weddell Sea: New observations on the Filchner-Ronne and Larsen C ice shelves and mode validation, J. Geophys. Res., 116, C06006, doi:10.1029/2011JC006949.
Knudsen, P., and O. Andersen (2002), Correcting GRACE gravity fields for ocean tide effects, Geophys. Res. Lett., 29(8), 1178, doi:10.1029/ 2001GL014005

Köhl, A., and D. Stammer (2008a), Decadal sea level changes in the 50-year GECCO ocean synthesis, J. Clim., 21, 1876-1890, doi:10.1175/ 2007JCLI2081.1.

Köhl, A, and D. Stammer (2008b), Variability of the meridional overturning in the North Atlantic from the 50 years GECCO state estimation, J. Phys. Oceanogr., 38, 1913-1930, doi:10.1175/2008JPO3775.1.

Kwok, R., G. F. Cunningham, H. J. Zwally, and D. Yi (2006), ICESat over Arctic sea ice: Interpretation of altimetric and reflectivity profiles, J. Geophys. Res., 111, C06006, doi:10.1029/2005JC003175.

Lin, M. C., W. J. Juang, and T. K. Tsay (2001), Anomalous amplifications of semidiurnal tides along the western coast of Taiwan, Ocean Eng., 28, 1171-1198, doi:10.1016/S0029-8018(00)00049-4.

Lyard, F., F. Lefèvre, T. Letellier, and O. Francis (2006), Modeling the global ocean tides: A modern insight from FES2004, Ocean Dyn., 56, 394-415, doi:10.1007/s10236-006-0086-x.

Ma, X. C., C. K. Shum, R. J. Eanes, and B. D. Tapley (1994), Determination of ocean tides from the first year of TOPEX/POSEIDON altimeter measurements, J. Geophys. Res., 99(C12), 24,809-24,820, doi:10.1029/ 94JC02140.

Munk, W. H., and D. E. Cartwright (1966), Tidal spectroscopy and prediction, Philos. Trans. R. Soc. A, 259, 533-583.

Padman, L., and S. Erofeeva (2004), A barotropic inverse tidal model for the Arctic Ocean, Geophys. Res. Lett., 31, L02303, doi:10.1029/2003GL019003.

Padman, L., H. A. Fricker, R. Coleman, S. Howard, and S. Erofeeva (2002), A new tidal model for the Antarctic ice shelves and seas, Ann. Glaciol., 34, 247-254, doi:10.3189/172756402781817752.

Parke, M. E., R. H. Stewart, D. L. Farless, and D. E. Cartwright (1987), On the choice of orbits for an altimetric satellite to study ocean circulation and tides, J. Geophys. Res., 92(C11), 11,693-11,707, doi:10.1029/ JC092iC11p11693.

Peacock, N. R., and S. W. Laxon (2004), Sea surface height determination in the Arctic Ocean from ERS altimetry, J. Geophys. Res., 109, C07001, doi:10.1029/2001JC001026.

Ray, R. D. (1993), Global ocean tide models on the eve of TOPEX/POSEIDON, IEEE Trans. Geosci. Remote Sens., 31, 355-364, doi:10.1109/36.214911.

Ray, R. D. (1998), Spectral analysis of highly aliased sea-level signals, J. Geophys. Res., 103(C11), 24,991-25,003, doi:10.1029/98JC02545.

Ray, R. D. (1999), A global ocean tide model from TOPEX/POSEIDON altimeter: GOT99.2, NASA Tech. Rep. NASA-TM-1999-209478, pp. 1-58, Goddard Space Flight Cent., Greenbelt, Md.

Ray, R. D. (2007), Propagation of the overtide $\mathrm{M}_{4}$ through the deep Atlantic Ocean, Geophys. Res. Lett., 34, L21602, doi:10.1029/2007GL031618.

Ray, R. D., and S. B. Luthcke (2006), Tide model errors and GRACE gravimetry: Towards a more realistic assessment, Geophys. J. Int., 167, 1055-1059, doi:10.1111/j.1365-246X.2006.03229.x.

Ray, R. D., D. D. Rowlands, and G. D. Egbert (2003), Tidal models in a new era of satellite gravimetry, Space Sci. Rev., 108, 271-282, doi:10.1023/A:1026223308107.

Ray, R. D., S. B. Luthcke, and J. P. Boy (2009), Qualitative comparisons of global ocean tide models by analysis of intersatellite ranging data, J. Geophys. Res., 114, C09017, doi:10.1029/2009JC005362.

Ray, R. D., G. D. Egbert, and S. Y. Erofeeva (2010), Tide predictions in shelf and coastal waters: Status and prospects, in Coastal Altimetry, edited by S. Vignudelli et al., pp. 191-216, Springer, New York., doi:10.1007/978-3-642-12796-0 8

Savcenko, R., and W. Bosch (2008), EOT08a-Empirical ocean tide model from multi-mission satellite altimetry, Tech. Rep. 81, 37 pp., Deutsches Geodätisches Forschungsinst, München, Germany.

Shum, C. K., et al. (1997), Accuracy assessment of recent ocean tide models, J. Geophys. Res., 102(C11), 25,173-25,194, doi:10.1029/97JC00445.

Xiu, P., F. Chai, L. Shi, H. Xue, and Y. Chao (2010), A census of eddy activities in the South China Sea during 1993-2007, J. Geophys. Res., 115, C03012, doi:10.1029/2009JC005657.

O. B. Andersen and Y. Cheng, DTU Space, Danish National Space Center, Technical University of Denmark, 2100, Copenhagen, Denmark. (cych@space.dtu.dk) 